PLEISTOCENE AXES IN SAHUL: A RESPONSE TO MORWOOD AND TRESIZE.

STEPHEN A. SUTTON

Archaeology of palaeoantbropologr

rhe oniveraity of New bagland

\title{
INTRODUCTION
}

False facts are highly injurious to the progress of science, for they endure long; but false views, if supported by some evidence, do little harm, for every one takes delight in proving their falseness: and when this is done, one path towards error is closed and the road to truth is often at the same time opened. (Darwin 1871:606).

This paper is written in response to ideas and information presented by Morwood and Tresize (1989) pertaining to the antiquity and distribution of axes in sahul and in particular to one axe from S.E. Cape York. It is felt that this response is necessary because, whilst Morwood and Tresize raise some important issues and identify some apparent trends in the late pleistocene of sahul, their paper also engenders some confusion about these and other issues. Whilst I will not contend that the axe is a "false fact" it is true that serious consideration to the validity of the inferences Morwood and Tresize present is necessary due to the nascent nature of our understanding of Pleistocene humans and Morwood and Tresize's suggestions in this regard.

It is not the primary intention of this paper to debate the validity of the date per se, of the quartzite axe reported from sandy Creek Rockshelter in S.E. Cape York but to outline some of the concerns which lead to an appropriate caution about the data. In addition; some "facts" are discussed which occur in the archaeological literature and which are reiterated by Morwood and Tresize (and others), and it is argued that they cause confusion about the real issues to which the data bears testimony.

It should be pointed out here that this does not of course reflect on the veracity of the authors. Just as it is the duty of the reader (of this or any paper) to objectively assess the data, it is beholden upon the discoverers to report their findings. The location of the axe 20 years ago and the capture of data from a more recent excavation, including a single 30,000 b.p. date, is viable grist for the archaeological mill. The argüment presented here suggests that while this is true, the most correct presentation of the data would be to speculate on the what the data really means and how it should be interpreted. Is the appropriate consignment of the data to the "in" or "out" or "pending" tray? 
The evidence in this case revolves around the location of an axe at the base of an excavation some 20 years ago by Tresize, and the reexcavation of the site by Morwood and acquisition of a C14 determination for the bottom of the gite of over 30,000 years $(31,900+700 /-600$. SUA 2870). The nature of the original excavation, including such things as the depth of removal units or spits, recording of artefacts/ features/stratigraphy etc. is not provided. Moreover, the specific context of discovery of the axe itself is not provided. Was the axe discovered in the course of trowelling, if trowels were used? If larger implements were used, say spades or shovels etc., how was the integrity of each spit maintained so that no mixing of sediments occurred in the course of excavation? Was the axe loose in the deposits? Was there any evidence of disturbance? Was it discovered first thing in the morning or after a break in excavation, perhaps falling out of a higher layer of sediment? The scant details provided, the long period of time which has elapsed since the discovery of the artefact combined with fact that the axe has since been lost places the sandy creek axe in a unique position. It certainly would appear to lie well outside the usual methods of data collection in Australian archaeology. Whilst personal asides about the quality of excavations and excavators abound in archaeological gossip, nonetheless it is hoped that minimum standards of data collection (Johnson 1980) now appear to prevail, providing some degree of reliability about the data recovered. However, even when modern standards of excavation are applied there is always room for speculation (Gould 1980:46). How then is the data in this case to be understood?

The data as they stand are of insufficient quality to be objectively assessed. This is a double edged sword in that whilst the reader may wish to ascribe the axe as an acceptable fact or otherwise, confirmation in either direction cannot be achieved. Recent debate in Australian archaeology has turned attention again to the various means of validating scientific theories or testing hypotheses (Gould 1980, Murray 1989, 1990, Tangri 1989a, 1989b). What is striking about the case of the missing axe is that no opportunity for refutation appears to exist and, despite the second excavation, no confirmation has been offered.

Confirmation might include fragments of axe or flakes with ground surfaces derived from the process of re-sharpening of axes on site etc. Even debatable evidence' such as the presence of manuported mafic rock such as Jones and Johnson (1985) describe and which Morwood and Tresize (1989:82) note may have been some form of confirmation. How does the reader interpret the fact that no such evidence is offered?

Other evidence may have been offered in support of the data. For example, of the two excavations which have been undertaken, sections or stratigraphic diagrams of the former only are presented. Given the nature of the claims made by Morwood and Tresize, it might be expected that some portrayal of the more recent excavation was made, and comparison provided. Even allowing for the best intentions under which the first excavation was undertaken, there appears to be no doubt that the latter excavation should provide the most accurate graphical detail about the site and its stratigraphy.

The data which are presented force the reader into a position of accepting Morwood and Tresize's interpretation on the basis of belief you either believe it or you don't simply because there is insufficient 
information upon which to base an objective re-assessment. A third position is possible, that of establishing a firm position on the fence and awaiting more information. This last option will probably be preferred by most readers and will indeed result in the inferences Morwood and Tresize propose not being accepted prematurely.

Any debate about the accuracy of the date of 32,000 b.p. would require the disclosure of a more complete set of data than Morwood and Tresize present for appraisal, and it is to be expected that such information will be forthcoming (papers presented by Morwood and Pearce at the 1990 AAA conference confirm this). Suffice it to say that it is now commonly expected that any attempt to push back a chronological frontier, in this case the antiquity of axe manufacturing and grinding technology, usually requires an established (and hopefully consistent) series of dates. Even when such data is presented, critique and peer review often result in considerable debate (eg. Bowdler 1990, Hiscock 1990, Roberts et al. 1990a, 1990b, 1990c). It is in this spirit, encompassed in Darwin's quotation (above) that the following is offered.

\section{IMPLICATIONS OF THE FIND}

Morwood and Tresize present an overall picture of the distribution of axes in the Pleistocene (Morwood and Tresize 1989:78) which tacitly suggests that there are broad connections between flaked and ground mafic rock axes, waisted blades from Melanesia and the large implements of the Kartan from Kangaroo Island. These connections in fact do not exist and what is presented is a conflation of artefacts which vary greatly in the technology of their manufacture, raw material and almost certainly in their function. Groube (1987:175) identifies that the waisted blades comprise several populations on the basis of their morphology alone.

Jones (1987) functional inferences about the nature of unground axes in Nuigini (i.e. the artefacts are used for clearing rainforest) is compared with both the use of edge ground artefacts in.N.E. Queensland (Horsfall 1987) and Kangaroo Island (Morwood and Tresize 1989:83). Whilst inferences of functional equivalence in the arena of rainforests might be extended over some periods of time, it is difficult to comprehend the connection between the rainforests and the environment of Kangaroo Island in the Pleistocene.

The most important point in regard to the use of all the large "axe-like" artefacts as some form of homogeneous group is the variation in their technology. The important phenomenon which Morwood and Tresize correctly identify (see also Godwin 1990) is the distribution of axe manufacturing technology, or its products, over most of the continent in the mid-to-late Holocene. They note that the restructuring of southern Australian communication networks and population growth is sequentially (at specific sites) associated with the expansion in the range of regular axe use. This may be the case, but it is incorrect to associate the technology of axe manufacture in the Holocene with that in the pleistocene, because our knowledge of the two is not comparable.

Our knowledge of the manufacture and distribution of axes in the Holocene is not inconsiderable (Binns and McBryde 1972, Dickson 1981, MCBryde 1986, 1988). Additional to McBryde's work, Hiscock (in press) has for some years been investigating the technology of manufacture at some of the larger axe manufacturing sites in the Mount Isa district. 
As well as containing several major quarries, one larger than $4 \times 1 \mathrm{~km}$ in extent, this area contains numerous smaller sites where a single or even a moderate number of axes have been manufactured. This work has demonstrated a standardisation of quarry products involving a streamlining of manufacturing techniques which might be expected in any large scale mass production venture. There is little doubt that this factory-like production was linked to the widespread distribution of axes throughout central Australia in the late Holocene. What is perhaps more striking is that. this same technology appears to have been conducted on smaller sites where the considerations of economies of scale do not apply.

One such site was located on Gin Creek, $15 \mathrm{~km}$ east of one of the large quarry sites near Mount Isa. This site was a single knapping floor resulting from the reduction of an elliptical metabasalt boulder weighing over $40 \mathrm{~kg}$. Refitting of the flakes by $B$. Huchet and subsequent analysis by us indicates that the technology of manufacture is virtually identical to that observed by Hiscock at the quarry. Figure 1 shows the conjoin sequence diagram which indicates that after appropriate platform preparation etc., three large flakes were removed from the boulder. Two of these were retouched on site and subsequently removed. The third was discarded. The casts of the flakes removed from the site portray the same pronounced bulb that Hiscock describes for the larger quarry. The retouching which occurs on site (artefacts $27-37$, and $38-77$ ) are all struck from the ventral gurface and remove the distal end of the flake, back to the pronounced bulb. This creates a partial bevel on the flakes distal end.

Although the analysis of material from Gin Creek has not been completed, it is sufficient to identify the technological strategy (cf. Hiscock and Mitchell 1990) as being the same as that applied to the mass production of axes at the major quarry to the west. Moreover, it demonstrates the kind of data which is available and is under investigation pertaining to Holocene axe manufacture. No such database exists for axes dating to the Pleistocene.

As such, not only is there no basis for comparison of unground Pleistocene artefacts with Holocene axes, there is little basis for comparison of the few which actually have edge-grinding. This situation will not change through further examination of Holocene axes but via the investigation of the technology of manufacture of axes from the Pleistocene. Morwood and Tresize do not provide any general discussion of this issue and given the unfortunate loss of the sandy creek axe, none which specifically relates to this artefact can be forthcoming.

\section{AXB FUNCTION}

We now come to the subject of function. Morwood and Tresize consider function in two ways; that suggested by Groube (1987) and Jones (Jones 1987) purporting that axes are used in the clearing of rainforest, and the use of axes in the pursuit of arboreal resources such as possums as suggested by McBryde (1977). Much of the former argument need not concern us here insofar as it relates to the large unground artefacts of PNG (and Kangaroo Island) which should not be considered in the same rubric as the widespread flaked and ground axes of the Australian Holocene for reasons outlined above. 


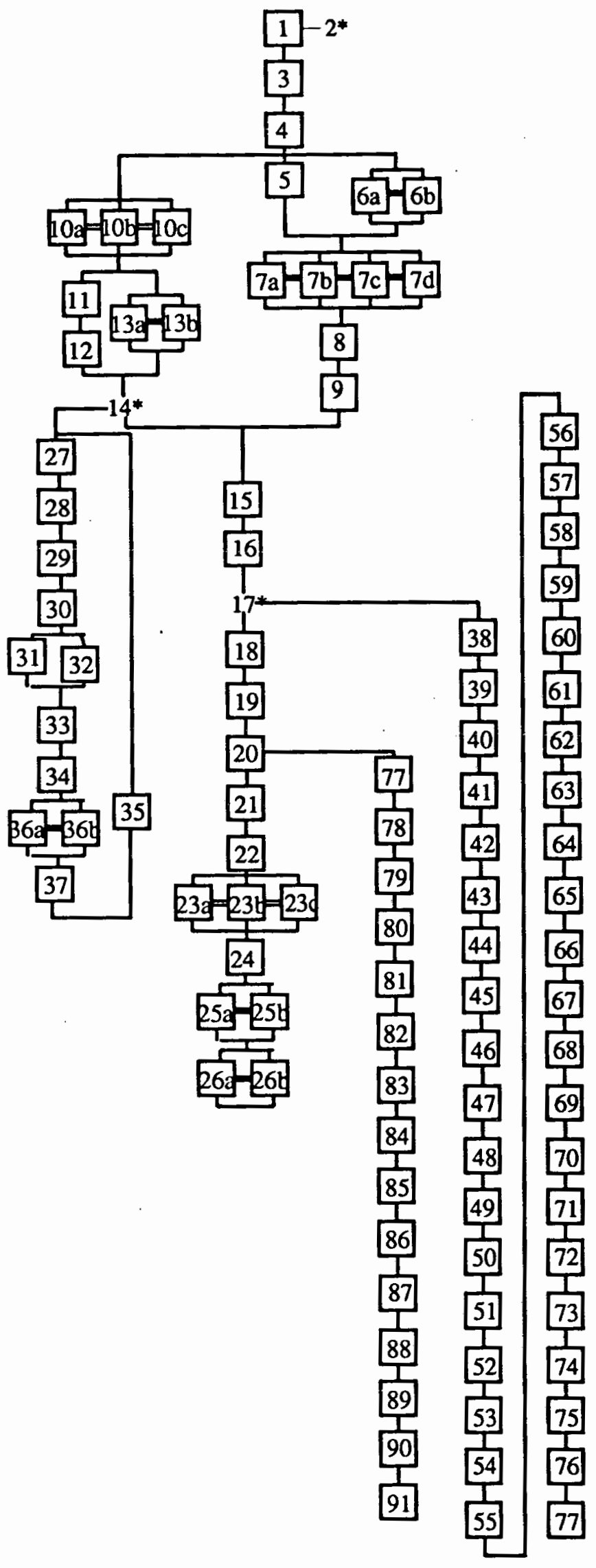

Figure 1. A conjoin sequence diagram (after Hiscock 1986) from the Gin Creek 1 site. Asterisks indicate artefacts not recovered on site. Artefacts 14 and 17 were reconstructed from casts. 
The second argument deserves closer -inspection. McBryde (1977) suggested that some correlation appeared to exist between an increase in the number of axes at Graman and a similar, though relative increase in the number of Phalangeridae in the sequence. Specifically, MNF for families were calculated in four levels, including the surface of the deposit, spanning a period of around 4000 years. McBryde's-presentation of the data (1977:237) suggests, on the basis of the relative percentages of Macropodids versus Phalangerids and other taxa which show no significant changes, that a significant increase Phalangerids took place through time. McBryde, notes the importance of these observations and states "the validity of these correlations must be rigourously tested" (1977:237). Morwood and Tresize (1989:85) and others (eg. McNiven 1988:153) have used McBryde's inferences as fact but have not carried out her request for rigourous testing of the correlation.

Subsequent to McBryde's article, Grayson (1984), has stated the shortcomings of presenting data in closed arrays; "Since percentages must sum 100, the fact that the relative abundance of one taxon increases at the same time another decreases may be telling us more about the nature of closed arrays than about the behavior of the variables in which we are really interested" (Grayson 1984:19). This has obvious implications for drawing inferences from the data as presented by McBryde. This data is presented in the form of bar graphs for various taxons showing MNI and percent of assemblage represented. It is not the MNI data but the closed array (percentages) which McBryde uses in construction of her inferences.

If we portray MCBryde's data and use the MNI data as is, without converting it into percentages (Figure 2) we see that McBryde's own data suggest that rather than an increase in Phalangerids, there is a marked decrease through time. This clearly does not support an argument about increasing use of arboreal resources.

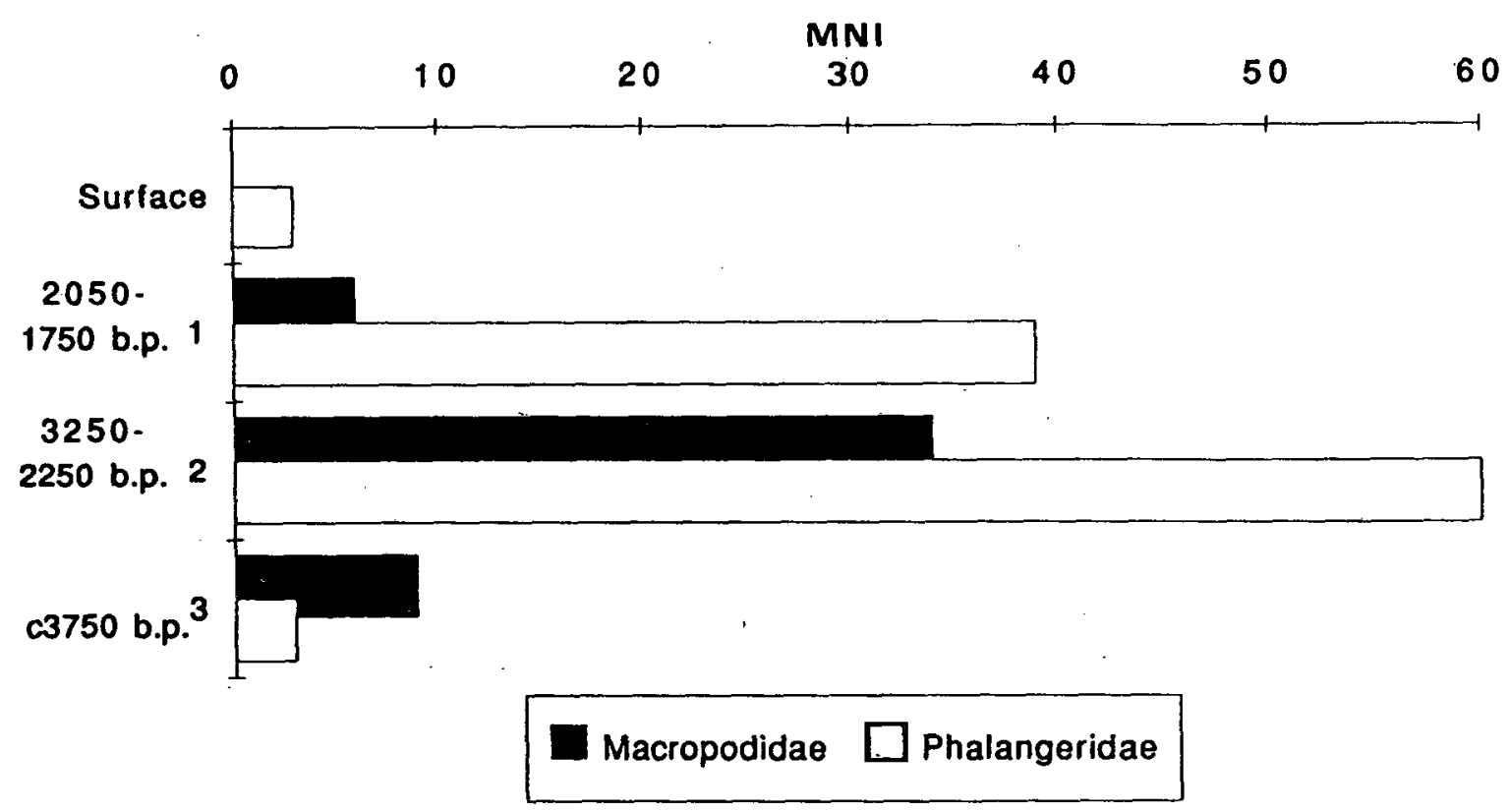

Figure 2. MiN of Phalangeridae and facropodidae from Graman (after Mcbryde 1977:237). 
Many Australian archaeologists rely on the use of ethnographic observations when educing inferences from archaeological data (cf. Meehan and Jones 1988). MCBryde looked to the ethnographic database to seek verification of her inference based on the archaeological data and noted that during contact times possum appeared to form the protein staple of the indigenes diet. However, other data from the same period indicate that at the time enormous numbers of macropods were being decimated by the colonising European population. On one property on the New England Tableland over 10,000 kangaroos were killed by European settlers in one year, and a further 20,000 were slaughtered during the next four years (Norton 1972:5). If this had effects on the availability of this particular sort of game, and it is difficult to imagine otherwise, it is quite understandable that in the final years of their traditional subsistence lifestyle, the Aboriginal inhabitants of the Tableland looked more often to possum as a sol:rce of protein. The singular impact of Europeans on Aboriginal foraging cannot of course be equated with a putative long term shift in subsistence patterns from kangaroos to possums during 3000 years of the late Holocene.

The most important conclusion Grayson (1984) draws concerns the validity of using MNI calculations in the assessment of relative taxonomic abundance in archaeological and palaeontological sites. His primary conclusion is that they are quite inappropriate for the purpose as presented by McBryde (1977). As such my presentation of the data from Graman is as likely to be as misleading as previous portrayals. If anything the spurious nature of the use of MNI as pointed out by Grayson further confirm that it is not appropriate to suggest that there is an increase in possum predation associated with the increased discard of axes at sites in the Holocene. Put another way, it is not a "fact" and McBryde's precautionary call for more rigourous testing of the hypothesis appears justified.

It seems reasonable to assert that axes are in some way functionally related to the presence of trees in a landscape, although one-to -one correlations such as "axes are for chopping out possums" are apt to be unwarranted. Axes are useful wherever a heavy, hard, durable, sharp, yet conveniently portable object is required (cf. Dickson 1981:100). In a situation where environment and technology conspire to leave stone, bone and wood as the fabric for virtually all human purposes, it is likely that axes will be useful. If wood is removed from the physical attributes of an ongoing human way of life, it is not surprising that a need for axes is also absent. The absence of axes on the Nullabor, (which of course means "no trees") can be seen in this light. In other areas the high-cost of transportation etc. (Morwood and Tresize 1989:85) appears to be met, even if sources were a great distance off, because in these areas there is a reason or need to have axes (i.e. wood). As such, whilst function is without doubt an important variable for consideration in the analysis of axes, studies of direct environmental/functional associations are likely to prove difficult (cf. O'Connell 1977). Morwood and Tresize may have redressed this situation if they had provided a consideration of the nature of axe use, say from ethnographic observations etc. Binford, for example (1986:551-2) describes the use of an axe (albeit steel) in the manufacture of another artefact. Conspicuously, this axe was not involved in extraction of arboreal food resources. Surely characterisation of the relative amount of axe use for maintenance of extractive and other items versus food extraction would be a relevant and prerequisite avenue of discussion here. As it happens I believe the constraints involved in discussing the function of axes at the level Morwood and Tresize propose 
means that the examination of the nature of their distribution and the technology of their manufacture are likely to be more rewarding.

\section{CURATION AND . PLEISTOCEINE SUBSISTENCE STRATEGIES}

Another important issue Morwood and Tresize mention is that of the nature of the subsistence strategies in evidence in Australia during the Pleistocene. In their scheme the presence of curated artefacts (axes) in a gystemic context indicates the existence of a logistically organised subsistence strategy. The logic appears to proceed: axes = curation = logistics, in this case extending well, back into sahul's Pleistocene (Morwood and Tresize 1989). They state that there is a "predominance of expedient stone artefact technologies in S.E. AsianAustralian prehistory" (Morwood and Tresize 1989:82) and set this as a foil for the appearance of "the earliest evidence for the use of curated items in this part of the world" (Morwood and Tresize 1989:82). It is worth noting that Binford (1972:189, 1973:144) describes Australian Aboriginal technology as being highly curated, but see Hiscock (1988:299-302) for a more complete discussion.

The reason for depicting some pleistocene Australians as logistically oriented collectors is not clear. Lourandos (1987:159) notes that the move toward more intensive systems of communication and social interaction during the Holocene might be seen as a move from expedient technology/foraging to curated technology/collecting. Morwood and Tresize (1989:85) in turn draw our attention to the nature of the changes during the Holocene and the role of axes in these changes. Although the main value of axes would appear to be in "increasing the efficiency of (arboreal) food procurement" (1989;85), the suggegtion that changes in the distribution of axes may be interpreted as "adaptive responses to changes in social, and demographic context" (1989:86) indicates that Morwood and Tresize have grander schemes in mind. Given the "fact" of the connection that is drawn between axes and social complexity Morwood and Tresize portray, a major conclusion must be that they are suggesting that the social changes believed to occur during the Holocene (eg. Lourandos 1983, 1984, 1987) are the result of the diffusion of that kind of system from small pockets in the north of Australia. It is even noted that in those areas where early axes occur the archaeology reveals. a. history of long-standing linguistic and artistic complexity (Morwood and Tresize 1989:84).

The depiction of "intensification" diffusing from some northern Australian Pleistocene homeland is somewhat different from the more commonly described mechanisms driving the process. These involve social forces (Lourandos 1983, 1984, 1987), demographic change (Beaton 1983, 1990) and a reasonable smattering of environmental constraints (Smith 1988). These are basically autochthonous developments, with the changes occurring as a result of social or biological forces which inevitably make themselves felt. Diffusion from outside Australia of the behaviours and technologies we now associate with the phenomenon of "intensification" has been suggested by Bowdler (1981:108,110). Clearly the appearance of the dingo at about the same time as significant changes in the archaeological record has been enigmatic and fuelled this speculation. Countering this argument, white and o'connell (1982:106123) suggest on the basis of dating and distribution of such things as Backed Blades and Points that the technology at least has a local origin. 
However, it is not the purpose of this paper to discuss such an hypothesis in detail. It should be clear that should a debate ever arige about a "proto-intengification homeland", a large number of aspects would need to be considered. However, of these, I believe the most important point where such an hypothesis would fail is that it does not address the more important questions raised by the intensification debate. These are questions of why, rather than where, which require an improvement in archaeological method and inference making if adequate answers are to be achieved. Why does the archaeological record of the past 5,000 years look like it does and not like the previous 5,000 years (cf. Binford 1981:25)? If the changes in the archaeological record can be attributed to particular behavioural changes, why did these changes take place? Moving the location of the origin will not solve this kind of issue and would not seem to offer any hope of aiding the progression of the discipline.

This being the case it is important to examine the nature of one of the underpinnings of Morwood and Tresize suggestion, namely that axes are curated artefacts, curated artefacts indicate logistically organised subsistence strategies and we find axes well back into the pleistocene; therefore Pleistocene Australians were logistically.organised.

If we accept curation as a valid framework for examination of the data, such as it is, then it is worth considering what a curated technology would involve. Binford (1979:270) describes logistic organisation thus:

Two major characteristics of systems organized logistically are that raw materials are rarely obtained through direct procurement strategies, and that the logistical operations of the system are supported by a wide-ranging Rcachings strategy which insures the dispersion in the habitat of goods and materials which might be needed later. (Original in italics).

Given Binford's definition and the data relating to the development of extensive networks for the dissemination of axes (Binns and McBryde 1972, McBryde 1986, 1988) and caching behaviour, coupled with his support of the logistic nature of the technology of the Australian Aborigines he observed, it would seem reasonable to view Holocene inhabitants of the country as just so. However, the very lack of evidence, especially for long distance movement and indirect procurement of axes would seem to lead to an inference that the pleistocene occupants of the continent were not logistically oriented at all, although perhaps axe users of the Holocene were!

Unfortunately, there are sound reasons why we should not accept curation as an appropriate framework for discussing these issues. Bamforth (1986) and Hiscock (1988) both raise substantial questions about the value of the concept of curation to improving our understanding of the past. Bamforth (1986:49) notes "the notion of curation is frequently encountered in the literature and yet adds few real insights to most discussions". Moreover ". no aspect of technology, with curation as a specific example, can be predicted solely from an understanding of subsistence-settlement organisation.." (Bamforth 1986:48). That is, no one-to-one correlations can or should be drawn between curation (however perceived) and logistic organisation. For example, White and Modjeska (1978:285) indicate that, although they consider the axes of the Duna "prime examples of "curated' tools", the nature of discard mitigates against ongoing curation processes. This 
means that a statement that "axes are curated artefacts" is relatively meaningless in the sense that the curation can not be measured per se and measurement, at least at an ordinal scale, is necessary if relative positions on a continuum from non-logistic to logistic are to be assessed.

Hiscock (1988) provides an important review of the use of the concept of curation by archaeologists attempting to formulate rules about the nature of fisher-gatherer-hunter behaviour for use in archaeological inference building. Like Bamforth, he argues that "curation, and its application to archaeological assemblages, is currently of dubious value" (1988:313). More important to this discussion, he points out that there is no identifiable direct correlation between curation of artefacts and collectors (1988:312). What he does note is that there are a large number of factors influencing fisher-gatherer-hunter stone artefact technology; "the conveyance of cultural information, the function of the artefacts, the nature of movements around the landscape, the extent of time stress and the availability and cost of stone material." (Hiscock 1988:313). Lumping all these together in a search for ordinal relationships on the forager-collector continuum effectively reduces our ability to understand past behaviours and it is these behaviours in which we are primarily interested.

This also has implications for the concept of "techno-complex" as used by Morwood and Tresize (1989:83) in that in particular locations, different amounts of the various constraints Hiscock identifies will act upon the technology. In some areas, where raw material is abundant and ubiquitous there will be no availability constraints and so on. This creates a scenario where different areas will display local strategies as responses to local constraints within regional and (rarely) continental technologies. This would seem to fit an emerging picture of local and regional technological variation in different parts of the continent (Hiscock 1988, sutton 1985). Any speculation about the relationship these strategies bear to "techno-complexes" is premature.

Another "fact" in Australian archaeological studies to which Morwood and Tresize refer, albeit briefly, is the appropriateness of comparison between the mainland and Tasmania. Such comparisons appear to occur because of what did not happen in Tasmania during the Holocene relative to the mainland. In the case of Morwood and Tresize it is noted that axes and the efficient system for the extraction of arboreal maminals which they are purported to represent (but see above) did not make it to Tasmania. Are we left to infer that this in some fashion abetted the putative degeneration of Tasmanian society suggested by Jones $(1977: 202-3)$ ? Is it to be supposed that Tasmania did not have intensification because it couldn't diffuse from northern Australia across Bass strait? Remember, of course, that the answer to such a question must be set against Jones' (1971) claims for improved efficiency in the manufacture of stone artefacts in, Holocene Tasmania (see also Sutton 1985$)$.

I have often been struck by the comparability of aspects of the Tasmanian archaeological data with that used to support arguments about intensification on the mainland; i.e., a comparison of Tasmania and the mainland portraying similarities rather than differences (but see Bowdler and Lourandos 1982). If we present the initial dates of occupation of sites in Tasmania during the Holocene in a fashion similar to that presented by Lourandos (1983:86) and Williams (1987:319) for 
sites in western Victoria, we see that, all things being equal, there is a very similar pattern (Figure 3 ). One could obviously infer from this that there was in fact an intensification in Tasmania, much as there was on the mainland, despite the lack of communication networks and axes. It is a small point but would appear to have larger implications. If this inference is correct it in turn places a major question mark over the importance of axes in terms of changes in a variety of aspects of culture which Morwood and Tresize (1989:84) allude to; language, communication networks and artistic complexity, which would "normally" appear to become more complex in association with archaeological patterns such as that seen in Figure 3. That is to say, there is a strong suggestion that there is no clear connection between axes, archaeological patterns such as that portrayed in Figure 3 and the cultural complexity we are familiar with, thanks to ethnographic accounts. It is in fact necessary to conduct considerably more research in an effort to "name our parts" (Davidson 1988), to understand the behavioural connections, if any, between the disparate data sets. As such, a synthesis like that Morwood and Tresize present, which focuses on one aspect of the data, with little information on behavioural connections between models and data is apt to be premature. Can we actually determine how culturally complex the fortunate pleistocene possessors of axes were? If Morwood's and Tresize's inference is not correct, then re-assessment of the means by which we determine social complexity and changes therein from archaeological data is needed. In particular, the use of initial or basal occupation dates is called into question (eg. Lourandos 1983:86, Morwood 1987:345, Williams 1987:319).

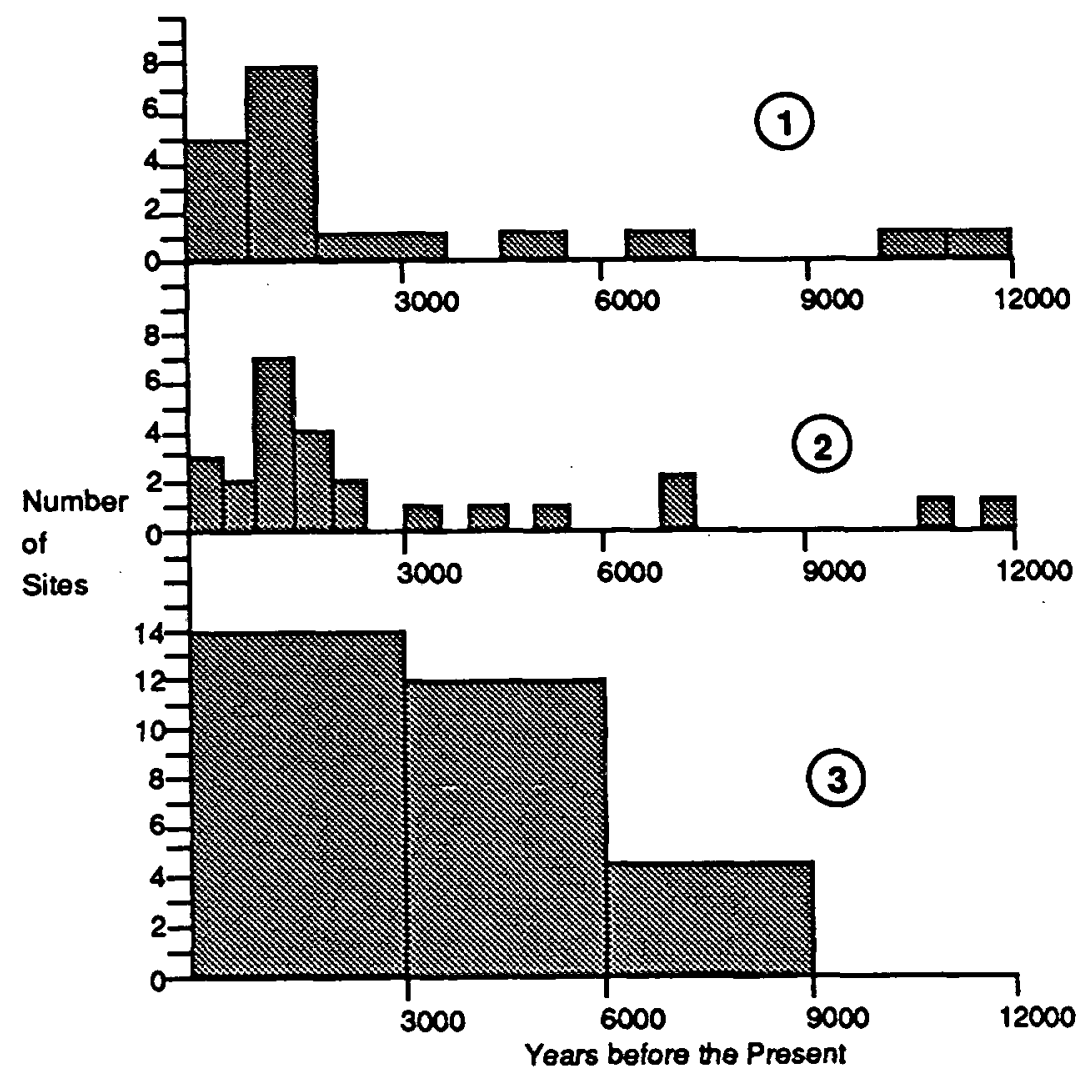

Figure 3. Initial occupation dates. 1 and 2 refer to southwestern Victoria, 3 refers to Tasmania (Western Victorian Data; 1, after Lourandos 1983:86, 2, Williams 1987:319. Tasmanian data after stockton 1981). 


\section{COMCLUSION}

This paper has sought to raise some substantive points about a number of "facts" which I believe are individually and collectively important to our understanding of the nature of the pleistocene of Australia. Morwood and Tresize' work is a valuable contribution to the development of our understanding of this issue, differences of opinion notwithstanding. This is because all the information needs to be thrown into the ring. In this sense, while the data preserted from sandy creek shelter are important, the expression of caution is necessary so that the axe does not become a "fact" prematurely and "endure long" inappropriately. It may be that the axe from S.E. Cape York is "genuine product" but given the nature of the collection of the data and their availability for re-assessment, it is argued that it is at least too early to accept it as a valid article upon which to base inferences - especially if these inferences are in turn based upon other flawed inferences.

Unfortunately, this re-assessment may be to late as the axe has now entered the broader realm of general knowledge as a fact. In a recent edition of a popular journal (Park 1991), the pleistocene axe appears, but caveats about the reliability of the data or inferences based upon it are nowhere to be seen.

\section{ACKNOWLEDGMENTS}

This paper has been substantially improved as a result of discusgions with Peter Hiscock and Iain Davidson who curbed my worst excesses. Iolanthe sutton and Luke Godwin read drafts and provided valuable comments. In spite of their help all responsibility for this paper must be vested in me.

\section{REFERENCBS CITED}

Bamforth, D. B. 1986 Technological efficiency and tool curation. American Antiquity 51 (1):38-50.

Beaton; J. M. 1983 Does intensification account for changes in the Australian Holocene record? Archaeology in Oceania. 18:94-97.

Beaton, J. M. 1990 The importance of population for prehistory. In B. Meehan and $N$. White (eds.), Bunter Gatherer Demography: Past and present. pp.23-40. Sydney: Oceania Monograph.

Binford, I. R. 1986. An Alyawara day: making mens knives and beyond. American Antiquity $51(3): 547-562$.

Binford, L. R. 1972. Contemporary model building; paradigms and the Current state of palaeolithic research. In D. L. Clarke. (ed.) Models in Archaeology. pp.109-166. London:Methuen.

Binford, I. R. 1973. Interassemblage variability - the Mousterian and the 'functional' argument. In C. Renfrew. (ed.), The Explanation of Culture Change. pp. 227-254. Surrey: Duckworth.

Binford, I. R. .1979. Organization and formation processes: looking at curated technologies. Journal of Anthropological Research. 35 (3) : 255-273. 
Binford, I.R. 1981 Bones: ancient men and modern myths. New York: Academic Press

Binns, R. A. and I. MCBryde. 1972 A Petrological Analysis of Groundedge Artefacts from Northern New south Wales. Canberra:Australian Institute of Aboriginal studies

Bowdler, s. 1981 Hunters in the Highlands: Aboriginal adaptation in the eastern Australian uplands. Archaeology in Oceania 16:99111 .

Bowdler, S. 199050,000 year old site in Australia-is it really that old? Australian Archaeology $31: 93$.

Bowdler, S. and H. Lourandos 1982. Both sides of Bass Strait. In S. Bowdler. (ed.) Coastal Archaeology in Eastern Australia. pp.121-132. Canberra:R.S.Pac.S.

Darwin, c. 1871 The descent of man and selection in relation to sex. London:John Murray

Dickson, F. P. 1981 Australian Stone Hatchets: a study in design and dynamics. Sydney:Academic Press

Godwin, I. 1990 Inside Information: settlement and alliance in the Holocene of northeastern N.S.W. Unpublished Ph.D. thesis, University of New England.

Gould, R. A. 1980 Living Archaeology Melbourne:Cambridge Univergity Press

Grayson, D. K. 1984 Quantitative zooarchaeology: topics in the analysis of archaeological faunas. New York:Academic Press

Groube, L., Chappell, J., Muke, J. and Price, D. 1986. A 40,000 yearold human occupation site at Huon Peninsula, Papua New Guinea. Nature $324: 453-5$

Groube, L. 1987 Waisted axes of Asia, Melanesia and Australia. In G. Ward (ed.) Archaeology at AKzaAs, Canberra. pp. 168-177. Canberra:Canberra Archaeological Society.

Hiscock, P, 1986 The conjoin sequence diagram: a method for describing conjoin sets. Queensland Archaeological Research 3:159-166.

Hiscock, P. 1988 Prehistoric settlement Patterns and Artefact Manufacture at Lawn Hill, northwest Queensland. Unpublished Ph.D thesis. University of Queensland.

Hiscock,P. 1990 How old are the artefacts at Malakunanja II? Archaeology in Oceania. 25(3):122-124.

Hiscock, P. in press The ancient miners of Mount Isa. MIMAG.

Hiscock, P. and S. Mitchell. 1990. Site Profiles, Quarries and stone Artefact Scatters. Australian Heritage Commission: Canberra 
Horsfall, N. 1987 Living in rainforest: the prehistoric occupation of North Queensland's humid tropics. Unpublished Ph.D thesis. James Cook University.

Johnson; I. 1980 Bytes from sites: the design of an excavation data recording system. In I. Johnson. (ed.) Holier Than Thou pp. 91-118. Canberra:R.S.Pac.s.

Jones, R. 1971 Rocky Cape and the Problem of the Tasmanians. Unpublished Ph.D thesis. University of Sydney.

Jones, R. 1977 The Tasmanian Paradox. In R.V.S. Wright (ed.) Stone Tools as Cultural Markers: change, evolution and complexity. Canberra: Humanities Press

Jones, R. 1987. Pleistocene life in the dead heart of Australia. Nature. 328:666.

Jones, R. and I. Johnson 1985 Deaf Adder Gorge: Lindner site, Nauwalabila 1. In R. Jones. (ed.), Archaeological Research in Kakadu Rational Park, PP.165-227. Canberra:A.N.P.W.S.

Lourandos, H. 1983 Intensification: a late Pleistocene-Holocene archaeological sequence in southwestern victoria. Archaeology in Oceania. 18:81-97.

Lourandos, H. 1984 Changing perspectives in Australian prehistory: a reply to Beaton. Archaeology in Oceania. 19:29-33.

Lourandos,F. 1987 Pleistocene Australia: Peopling a Continent. In O. Soffer, (ed.), The Pleistocene old Horld, Pp. 147-165. New York:Plenum Press.

McBryde, I. 1977 Determinants of assemblage variation in New England prehistory: Environment, subsistence economics, site activities, or cultural tradition? In R.V.s. Wright (ed.) stone Tools as Cultural Markers: change, evolution and complexity, pp.225-251. Canberra:Humanities Press.

McBryde, I. 1986. Artefacts, language and social interaction: 'a case study from S.E. Australia. In G.N. Bailey and P.Callow (eds.) stoneage Prehistory: Studies in memory of C. McBurney. pp.8793. London: Cambridge University. Press.

McBryde, I. 1988 Goods from another country. In D. J. Mulvaney and J. P. White (eds.) Australians to 1788. . Sydney:Fairfax, Syme and Weldon.

McNiven, I. 1988 Brooyar Rockshelter: a late Holocene seasonal hunting camp from southeast Queensland. Queensland Archaeological Research 5:133-160.

Meehan, B. and R. Jones (eds.) 1988 Archaeology with Ethnography: an Australian Perspective. Canberra: R.S.Pac.S., The Australian National University.

Morwood, M.J. 1987 The archaeology of social complexity in south-east Queensland. Proceedings of the Prehistoric society 53:337350 . 
Morwood, M.J. and. P. J. Tresize 1989 Edge-ground axes in Plelstocene Greater Australia: New evidence from S.E. Cape York. Queensland Archaeological Research 6:77-90.

Murray, T. 1989 Socio-political values and archaeological research: a rejoinder to Tangri. Australian Archaeology 29:53-60.

Murray, T. 1990 Why plausibility matters. Australian Archaeology $31: 98-102$.

Norton, B. E. 1972 Grasslands of the New England Tableland in the 19th Century. Armidale and District Historical society Journal $15: 1-13$.

O'Connell, J. F. 1977 Aspects of variation in central Australlan lithic assemblages. In R.V.S. Wright (ed.), stone Tools as Cultural Markers: change, evolution and complexity, pp.269281. Canberra:Humanities Press.

Park, A. 1991 The Pilot who Became a Tribal Elder. Australian Geographic 21:116-117.

Roberts, R. G., R. Jones and M. A. Smith 1990a Early dates at Malakunanja II; a reply to Bowdler. Australian Archaeology $31: 94-97$.

Roberts, R. G., R. Jones and M. A. Smith 1990b Thermoluminesence dating of a 50,000-year-old human occupation site in northern Australia. Nature 345:153-156.

Roberts, R. G., R. Jones and M. A. Smith 1990C stratigraphy and statistics at Malakunanja II: a reply to Hiscock. Archaeology In Oceania $25(3): 125-129$.

Smith, M. A. 1988 The pattern and timing of prehistoric settlement in Central Australia. Unpublished Ph.D. Thesis:University of New England.

stockton, J. 1981 Radiocarbon dates for archaeological sites in Tasmania. Australian Archaeology 12:97-101

Sutton, S. A. 1985 Warragarra stone: a technological analysis of a stone artefact assemblage from central Tasmania. Unpublished B.A. (Hons) thesis:University of New England.

Tangri, D. 1989a Early physical anthropology, confirmation and Australian Aboriginal brains. Australian Archaeology 28:26-34.

Tangri, D. $1989 \mathrm{~b}$ The hand that mocked: a rejoinder to Murray. Australian Archaeology 29:61-66.

White, J.P. and N. Modjeska 1978 Acquirers, users, finders, 10sers: the use axe blades make of the Duna. Mankind 11:276-287.

White, J.P. and J.F. O'Connell 1982 A Prehistory of Australla, New Guinea and Sahul. Sydney: Academic Press.

Williams, E. 1987 Complex hunter-gatherers: a view from Australla Antiquity .61:310-321. 